Berkala Ilmu Perpustakaan dan Informasi, Vol. 15, No. 2, Desember 2019, Hal. 124-136 DOI: 10.22146/bip.38264

ISSN 1693-7740 (Print), ISSN 2477-0361 (Online)

Tersedia online di https://jurnal.ugm.ac.id/bip

\title{
Analisis sitiran skripsi Program Studi Ilmu Perpustakaan Fakultas Ilmu Administrasi Universitas Brawijaya tahun 2015-2017
}

\author{
Dwi Eliana Sari, Muhammad Rosyihan Hendrawan \\ ${ }^{1}$ Program Studi Ilmu Perpustakaan, Fakultas Ilmu Administrasi Universitas Brawijaya \\ e-mail: elianadwi199@gmail.com
}

Naskah diterima: 23 Agustus 2018, direvisi: 1 Mei 2019, disetujui: 26 Juli 2019

\begin{abstract}
ABSTRAK
Pendahuluan Penelitian ini mengkaji perilaku penelitian (research behaviour) dari lulusan Program Studi Ilmu Perpustakaan Fakultas Ilmu Administrasi Universitas Brawijaya berkaitan dengan komunikasi ilmiah diantara para peneliti.

Metode Penelitian Penelitian deskriptif dengan pendekatan kuantitatif ini dilakukan melalui metode pengambilan data berupa dokumentasi dan observasi dari sembilan puluh empat skripsi.

Data Analisis. Analisis data yang digunakan pada penelitian ini adalah analisis statistik deskriptif.

Hasil dan Pembahasan. Penelitian ini memberikan hasil yaitu 1) Berdasarkan karakteristik literatur, jenis literatur paling banyak disitir adalah buku dengan total 6.074 sitiran $(66,8 \%)$, berdasarkan sumber, dokumen tercetak lebih dominan digunakan, yaitu 8.236 sitiran (90,6\%), bahasa Indonesia dominan disitir yaitu 8.116 $(88,25 \%)$ dan $6.617(73,3 \%)$ sitiran memiliki rentang usia 0-10 tahun. 2) Pengarang dengan jumlah paling banyak disitir yaitu 542 sitiran $(6,91 \%)$ adalah Sugiyono. 3) Paro hidup literatur yang disitir pada sumber data tersebut adalah 10 tahun.

Kesimpulan dan Saran. Berdasarkan temuan di atas, perilaku penelitian (research behaviour) dapat diketahui, sehingga dapat dijadikan pertimbangan bagi perpustakaan perguruan tinggi, utamanya dalam penentuan kebijakan pengembangan koleksi dan penyiangan, juga bagi administrator pendidikan di fakultas dapat lebih memberikan kontrol terkait kebijakan dalam hal menyitir.
\end{abstract}

Kata kunci: Bibliometrika; Analisis sitiran; Ilmu perpustakaan; Program sarjana

\section{ABSTRACT}

Introduction. This paper investigate the research behaviour in Undergraduate Program of Library Science Faculty of Administrative Science Universitas Brawijaya.

Data Collection Method. This research uses descriptive methods with quantitative approach through documentation and observation for data collection, a number of ninety-four undergraduate theses are explained in this study.

Data Analysis. Data analysis used in this study is descriptive statistical analysis.

Results and Discussions. This study has several result: 1) The characteristics of literature based on form type is book which most often used with 6.074 times $(66,8 \%)$, after that, literature in print is most frequently cited literature with the 8.236 times $(90,6 \%)$, then literature in Indonesian probably cited with the 8.116 times $(88,25 \%)$, the amount of 6.617 times (73,3\%) use literature from 0 to 10 years.2) Author that probably cited was Sugiyono with 542 times (6,91\%). 3) halflife ofliterature is 10 years.

Conclusions. Based of the findings, the research behaviour was defined, so the provided suggestion for collection developmet and weeding policies in the the university library, also for administrators of education in the faculty to provide more control over policies in terms of citation.

Keywords: Bibliometrics; Citation analysis; Library science; Undergraduate program 


\section{A. PENDAHULUAN}

Setiap mahasiswa yang menempuh pendidikan di lingkup perguruan tinggi pada masing-masing jenjang memiliki kewajiban untuk menyelesaikan tugas akhir sebagai syarat untuk memperoleh suatu gelar, salah satunya yaitu skripsi. Menurut Pedoman Penyusunan dan Ujian Skripsi Program Sarjana (S1) Fakultas Ilmu Administrasi Universitas Brawijaya Malang 2012/2013, skripsi adalah karya tulis ilmiah yang disusun oleh seorang mahasiswa sesuai dengan bidang studinya, berdasarkan dari hasil penelitian lapangan dan atau kepustakaan sebagai tugas akhir dalam studi formalnya di Fakultas Ilmu Administrasi, Universitas Brawijaya (Fakultas Ilmu Administrasi Universitas Brawijaya, 2012).

Skripsi memiliki kriteria yaitu berfokus pada salah satu isu sentral sesuai salah satu disiplin ilmu yang dikajinya, berdasarkan kajian empirik terhadap teoritik tertentu berdasarkan hasil pengamatan, observasi lapangan maupun telaah pustaka sesuai permasalahan yang dikaji dengan berpedoman pada kaidah penulisan karya ilmiah (Mutaqin, 2015). Melalui pembahasan, maka dapat diketahui bahwa acuan dari skripsi adalah adanya teori yang digunakan sebagai rujukan untuk menjelaskan suatu gejala di lapangan. Penggunaan literatur (bahan pustaka) sebagai rujukan ditujukan untuk menguji teori yang berkaitan dengan menyertakan sitiran atau kutipan yang relevan. Penyertaan sitiran dalam penelitian telah dijelaskan dalam Peraturan Kepala Lembaga Ilmu Pengetahuan Indonesia Nomor 06/E/2013 tentang Kode Etika Peneliti kode ketujuh, sebagai berikut yaitu "pengakuan sumbangan berbentuk pujian, kutipan atau sebagai kepengarangan bersama harus disebutkan jika gagasan-gagasan penyumbang tersebut telah mempengaruhi secara berarti isi karangan seorang peneliti" (Lembaga Ilmu Pengetahuan Indonesia, 2013).

Literatur yang digunakan pada skripsi dapat diperoleh dari perpustakaan. Salah satu layanan yang diberikan oleh perpustakaan adalah penyediaan koleksi. Koleksi merupakan aspek penting pada sebuah perpustakaan karena merupakan fondasi dari perpustakaan dan sumber kunci untuk menemukan informasi sesuai kebutuhan pengguna (Mairaj \& Naseer, 2013). Tabel 1 merupakan statistik koleksi yang didapat dari hasil observasi data di Perpustakaan Universitas Brawijaya tahun 2017.

Tidak ada satu pun perpustakaan mampu menyediakan informasi yang dibutuhkan oleh setiap orang, sama halnya dengan perpustakaan di lingkup universitas. Adapun salah satu upaya yang dapat dijadikan alat untuk mengetahui dampak keilmuan adalah menggunakan bibliometrika. Penggunaan indikator yaitu bibliometrika sebagai bahan evaluasi suatu bidang pengetahuan diakui sebagai teknik penting dan alat untuk belajar, menilai dan mendeteksi faktor penentu fenomena dalam kegiatan produksi ilmiah (Arao et al., 2015). Sementara itu, Smith (2017) menjelaskan bahwa "bibliometrics is essentially the quantitative analysis of publication outputs measuring and analysing the ways in which academic papers are published and cited". Metode yang umum digunakan dalam kajian bibliometrika adalah analisis sitiran. Analisis sitiran menguraikan frekuensi dan pola sitasi artikel dan buku. Penggunaan analisis sitiran pada publikasi ilmiah dilakukan dengan pemeriksaan literatur dalam dokumen untuk kemudian diketahui frekuensi dan pola pada publikasi tersebut (Rubin, 2016). Adapun hasil atau manfaat dari penelitian, kemudian akan dinilai berdasarkan analisis ini.

Melalui kajian bibliometrik menggunakan analisis sitiran dengan kajian pola sitiran, pola kepengarangan dan tingkat keusangan literatur ini diharapkan dapat memberikan gambaran secara nyata terkait penggunaan literatur yang disitir oleh mahasiswa Program Studi Ilmu Perpustakaan FIA UB tahun 2015-2017 dalam menyusun skripsi sehingga Perpustakaan Universitas Brawijaya mengetahui kekuatan koleksi dan dapat dijadikan sebagai evaluasi dalam pengembangan maupun penyiangan koleksi yang mana diketahui belum terdapat penelitian sebelumnya.

\section{B. TINJAUAN PUSTAKA}

Kajian mengenai analisis sitiran jurnal maupun koleksi lain telah dilakukan baik di 
Indonesia maupun luar negeri. Kajian tersebut antara lain dilakukan oleh Guninda (2015) mengenai analisis sitiran jurnal pada skripsi mahasiswa Jurusan Manajemen tahun 2014 di Perpustakaan Fakultas Ekonomika dan Bisnis Universitas Diponegoro. Penelitian ini bertujuan untuk mengetahui tingkat pemakaian jurnal yang disitir dan usia keusangan atau paro hidup literatur dengan populasi yaitu seluruh skripsi mahasiswa Jurusan Manajemen tahun 2014 di Perpustakaan Fakultas Ekonomika dan Bisnis. Sampel ditentukan dengan teknik sampling jenuh sejumlah 177 skripsi. Desain penelitian yang digunakan adalah kuantitatif dan jenis penelitiannya adalah bibliometrika dengan analisis sitiran. Metode pengumpulan data dilakukan dengan analisis dokumen dan wawancara. Penelitian ini menghasilkan tingkat pemakaian jurnal yang disitir berjumlah 1794 sitiran dan jurnal yang paling banyak disitir adalah Journal of Finance, serta usia keusangan jurnal yang disitir adalah 7 tahun. Tahun tertua dari literatur jurnal yang disitir adalah 1942 dan tahun termuda adalah 2014.

Adapun kajian yang di lingkup internasional terdapat kajian mengenai analisis sitiran untuk program magister dan doktor sebagai penilaian penggunaan sumber daya perpustakaan, dengan hasil menunjukkan bahwa persentase sitiran buku lebih besar daripada jurnal. Buku dalam format tercetak maupun jurnal tercetak dan elektronik, dengan bahasa Inggris lebih dominan digunakan. Usia rata-rata literatur yang disitir adalah 15 tahun, yang mana buku lebih tua dari pada jurnal, selain itu terdapat $95 \%$ jurnal dan $82 \%$ buku tersedia di perpustakaan. Temuan ini membenarkan penilaian terkait kemampuan perpustakaan universitas yang menjawab kebutuhan lulusan mahasiswa Departemen Sosiologi dan Antropologi (Rosenberg, 2015). Melihat beberapa penelitian tersebut, maka dalam penelitian ini menunjukkan perbedaan khusus, yaitu: tingkat pemanfaatan (sitiran) berdasarkan karakteristik serta paro hidup literatur yang disitir pada skripsi mahasiswa Prodi Ilmu Perpustakaan FIA UB tahun 2015-2017 guna mengetahui komunikasi ilmiah para ilmuwan berdasarkan kegiatan sitir menyitir juga mengetahui sumbangsih para ilmuwan terhadap perkembangan ilmu pengetahuan sesuai bidangnya masing-masing, selain itu dapat bermanfaat sebagai bahan evaluasi untuk pengembangan maupun penyiangan koleksi bagi Perpustakaan Universitas Brawijaya pada umumnya dan Perpustakaan Fakultas Ilmu Administrasi khususnya.

1. Analisis Sitiran

Analisis sitiran merupakan metode bibliometrika untuk menguji frekuensi dan pola sitiran artikel dan buku, sehingga dapat membuktikan hubungan antara karya dan peneliti pada literatur ilmiah (Michael, 2013). Analisis sitiran juga dapat dinyatakan dengan pengujian yang menjelaskan pola referensi dalam publikasi ilmiah (Wallace \& Fleet, 2012). Berdasarkan beberapa definisi tersebut, dapat disimpulkan bahwa analisis sitiran merupakan studi berkaitan mutu dokumen, mengenai sitiran pada publikasi ilmiah guna mengetahui komunikasi ilmiah dengan mengevaluasi produktivitas, kualitas dan dampak penelitian dalam pengembangan ilmu pengetahuan.

2. Ruang Lingkup dan Parameter Analisis Sitiran

Kajian bibliometrika memuat ulasan literatur maupun penghitungan rujukan berdasarkan dokumen yang disitir. Sumber yang digunakan dalam penelitian biasanya dapat dikategorikan menjadi 3 jenis, yaitu: primer, sekunder, dan tersier. Sumber primer memberikan bukti langsung dari suatu topik yang sedang dikembangkan pada sebuah proyek penelitian dan secara umum penting digunakan dalam proses penelitian. Sumber sekunder menyediakan analisis dan diskusi oleh para peneliti yang telah memeriksa sumber-sumber primer kemudian dicari untuk mengeksplorasi signifikansi tersebut, sedangkan sumber tersier memberikan ikhtisar dan sinopsis masalah yang diangkat oleh sumber sekunder sehingga dapat membantu peneliti mengidentifikasi sumber primer dan sekunder. Semua memainkan peran yang cukup membantu seorang peneliti 
dalam mengembangkan suatu proyek (Alderman, 2014).

3. Fungsi Sitiran

Fungsi sitiran dalam karya ilmiah dapat meliputi: a) Petunjuk arah (sign posting), sitiran mengarahkan pembaca ke sumber lain. Alasan menyitir tersebut ada 3 hal yaitu membantu atau menarik perhatian pembaca yang kurang informasi, mempertahankan argumen sesuai jalur dan menghemat ruang, b) Pendukung (Supporting), dukungan sitiran membantu penulis untuk membenarkan topik penelitian, metode, dan klaim penulis, c) Kredit (Credit), sitiran mengindikasikan pengakuan atas ide atau metode orang lain. Hal ini terkadang diungkapkan dalam istilah "memberi penghormatan" kepada sumber, di saat lain para informan mengedepankan "pembelaan diri" motivasi, sitiran yang memperjelasnya, bahwa pengarang tidak mengklaim sebagai pencetus konsep yang disitir, d) Posisi (Position), posisi sitiran dalam hal ini memungkinkan penulis untuk mengidentifikasi perwakilan dan sudut pandang yang berbeda dan patut dicontoh; menjelaskan sudut pandang peneliti secara rinci; dan melacak perkembangan seorang periset/ pemikiran pada bidang yang telah dilakukan, e) Pelibatan (Enganging), pelibatan sitiran muncul ketika penulis berada dalam dialog kritis dengan sumber referensi, f) Bangunan (Building), yaitu ketika penulis menggunakan sumber berupa metode atau ide sebagai fondasi yang dapat dikembangkan lebih jauh, g) Keterikatan (Tying), keterikatan sitiran ini menghubungkan penulis dengan metode sumber lain; pemikiran khusus /tradisi disipliner; atau perdebatan tentang isu-isu spesifik, h) Advertising, sitiran sebagai iklan yang mengingatkan pembaca baik pada karya penulis sebelumnya, atau karya orang lain, i) Masa Depan (Future), sitiran ini berfungsi untuk menyusun rencana penelitian di masa depan. j) Kompetensi (Competence), sitiran membantu menggarisbawahi keahlian mengenai pengetahuan tentang bidang dan kemampuan mereka untuk melakukan penelitian, k) Topik (Topical), sitiran topikal memungkinkan penulis untuk menunjukkan penelitian yang menjadi perhatian dengan isu-isu tertentu. (Harwood, 2009).

4. Kajian Analisis Sitiran

a. Karakteristik literatur, aspek karakteristik yang dianalisis adalah: 1) Pola sitiran, memiliki kajian berkaitan jumlah sitiran maupun jumlah oto sitiran (self citation); dan karakteristik atau sifat literatur sebuah jurnal atau buku mencakup jenis, tahun terbit, usia, bahasa pengantar literatur, serta peringkat majalah dari literatur yang disitir oleh penulis, 2) Pola kepengarangan, yaitu memiliki kajian kepengarangan berkaitan jumlah penulis, penulis paling sering disitir dan pengarang tunggal atau ganda (Sutardji, 2011). Kajian tersebut dapat diajukan sebagai acuan untuk pertimbangan dalam pengembangan koleksi dan mengukur pengaruh intelektual ilmuwan berdasarkan sitiran yang digunakan atau dapat juga disebut dengan karakteristik komunikasi ilmu pengetahuan.

b. Keusangan literatur, istilah ini pertama kali dikemukakan Line dan Sandison sebagai berkurangnya validitas dari kegunaan informasi seiring perkembangan zaman (Sangam, 2013). Hal ini ditemukan dalam beragam subjek dan negara, tergantung pada faktor alam, karakteristik subjek dan lain-lain. Tipe keusangan (obsolescence) literatur terdiri dari 4 jenis, yaitu: (i) Diachronous Obsolescence, merupakan jenis keusangan yang mengukur umur sejumlah dokumen melalui pengkajian tahun publikasi dari sitasi yang diterima dokumen, misalnya melalui ukuran berupa Halflife atau paro hidup literatur; (ii) Diasynchronous obsolescence atau multisynchronous 
obsolescence, merupakan jenis keusangan yang mengukur umur sejumlah dokumen sambil mempertimbangkan perkembangan subjek dokumen tersebut; (iii) Multisynchronous obsolescence, merupakan jenis keusangan yang mengukur umur sekelompok dokumen yang diterbitkan pada suatu kurun tertentu. Kata multi disini berarti kurun waktu beberapa tahun; (iv) Synchronous Obsolescence, yaitu jenis keusangan yang mengukur umur dokumen dengan mengkaji tahun publikasi referensi dokumen tersebut, misalnya median citation age (median umur sitiran) (Mustafa, 2010). Kajian terkait keusangan ini dapat digunakan untuk mengetahui keusangan suatu literatur bidang tertentu dengan menggunakan rumus median literatur.

\section{METODE PENELITIAN}

Penelitian ini menerapkan jenis penelitian deskriptif dengan pendekatan kuantitatif melalui teknik bibliometrika evaluatif yaitu analisis sitiran. Populasi pada penelitian ini yaitu 123 skripsi mahasiswa Program Studi Ilmu Perpustakaan FIA UB lulusan tahun 20152017 pada Perpustakaan Universitas Brawijaya. Adapun sampel yang digunakan adalah 94 skripsi yang didapat melalui penggunaan metode pengambilan sampel stratified proportionate random sampling yaitu memungkinkan setiap kelompok tahun dapat diteliti secara proporsional dapat dilihat pada Tabel 2. Adapun objek kajian penelitian adalah daftar pustaka yang tercantum pada keseluruhan sampel tersebut. Jumlah sampel ditentukan menggunakan rumus Slovin dengan margin of error 5\% (Darmawan, 2014), sebagai berikut:

$$
n=\frac{N}{1+N e^{2}}, n=\frac{123}{1+123 \cdot 0,05^{2}}=94
$$

Keterangan: $\mathrm{N}=$ ukuran sampel, $\mathrm{n}=$ banyaknya sampel, $\mathrm{e}=$ Presisi yang digunakan

Pada penelitian berikut, observasi dan dokumentasi dijadikan sebagai metode pengumpulan data yang digunakan. Observasi cenderung diarahkan pada pengamatan terkait koleksi perpustakaan dan metode dokumentasi digunakan oleh peneliti untuk memperoleh data sitiran skripsi mahasiswa program studi ilmu perpustakaan tahun 2015-2017 guna memperkuat fakta dan pelengkap sesuai kebutuhan dan tujuan penelitian. Tahapan teknik pengumpulan data dilakukan peneliti dalam beberapa langkah, yaitu: a) pemilihan skripsi yang mengkaji bidang Ilmu Perpustakaan tahun 2015-2017 dari katalog daring (online) Perpustakaan Pusat Universitas Brawijaya (lib.ub.ac.id), b) pencarian skripsi yang akan digunakan sebagai sumber data terdapat di Perpustakaan Universitas Brawijaya untuk dilihat daftar rujukannya, kemudian di fotokopi untuk digunakan sebagai sumber data, c) memeriksa kelengkapan dari daftar pustaka setiap judul skripsi, d) memasukkan data ke dalam program Excel yang terdiri dari dua bagian, Tabel 3 merupakan tabel panduan pengumpulan input data penelitian tersebut.

Setelah melakukan pengumpulan data, maka tahap selanjutnya adalah analisis data. Analisis data ditujukan untuk menjawab rumusan masalah penelitian. Pada tahap ini, data yang telah dikumpulkan, disederhanakan, diolah dan disajikan dalam bentuk tabel dan grafik sehingga mudah dibaca dan diinterpretasikan untuk mencari makna secara lebih luas. Adapun pada tahapan analisis data penelitian ini digunakan metode analisis data statistik deskriptif yaitu penyajian data melalui tabel, grafik, persentase, median, dan modus sesuai dengan pembahasan, yaitu pola sitiran, pola kepengarangan dan keusangan literatur, sebagai berikut:

a. Pola sitiran, untuk menganalisis terkait pola sitiran meliputi jenis, sumber, bahasa dan usia yang sering disitir dilakukan dengan menggolongkan data sesuai pembahasan yaitu jenis literatur (buku, majalah, jurnal, artikel, skripsi, tesis dan jenis lain), sumber literatur (tercetak dan elektronik), bahasa literatur (bahasa Indonesia dan bahasa Inggris) dan usia literatur ke dalam tabel. Selanjutnya berdasarkan hasil dari pengelompokan dan penghitungan dibuat peringkat yang paling sering disitir, hasil 
penentuan peringkat tersebut kemudian dilakukan hitungan persentase, disajikan dalam bentuk tabel dan melakukan interpretasi terhadap hasil.

b. Pola kepengarangan, hanya nama pengarang atas nama orang yang dihitung, sehingga untuk pengarang atas nama badan, instansi, atau lainnya tidak diikutsertakan. Hasil dari penghitungan dalam bentuk tabel tersebut kemudian diinterpretasi terkait adanya oto sitiran (self citation) yang mencakup jumlah penulis dan penulis yang paling sering disitir. Untuk menganalisis pengarang yang paling sering disitir dilakukan dengan memasukkan data nama pengarang ke dalam tabel. Selanjutnya berdasarkan hasil dari penghitungan dibuat peringkat, kemudian dilakukan hitungan persentase disajikan dalam bentuk tabel dan melakukan interpretasi terhadap hasil.

c. Keusangan literatur, untuk menganalisis keusangan literatur dilakukan dengan memasukkan data tahun terbit literatur pada tabel selanjutnya untuk mengetahui paro hidup atau lama keusangan literatur digunakan rumus median literatur untuk kemudian ditentukan literatur yang usang dan belum usang dalam bentuk persentase serta melakukan interpretasi terhadap hasil. Literatur dapat dikatakan usang ketika melebihi batas usia paro hidup literatur, begitu pula sebaliknya literatur dapat dikatakan belum usang ketika memiliki angka di bawah batas usia paro hidup literatur.

\section{HASILDAN PEMBAHASAN}

Suatu sitiran dapat dianalisis ketika memenuhi kelengkapan informasi bibliografi dalam penulisan daftar pustaka. Pada penelitian ini, terdapat 66 sitiran yang tidak mencantumkan tahun dan 9 sitiran yang tidak mencantumkan nama pengarang pada daftar pustaka sehingga tidak dapat dianalisis lebih lanjut. Adapun skripsi yang tidak menyertakan data bibliografi secara lengkap terdapat 26 $(27,66 \%)$ dari total 94 skripsi yang dijadikan sebagai sampel. Selanjutnya, pada pembahasan pola kepengarangan, makna pengarang yang dimaksud yaitu pengarang atas nama pengarang pertama saja (jika literatur ditulis oleh lebih dari 2 pengarang), kemudian untuk pengarang atas nama badan, lembaga, institusi, dinas dan lainnya tidak diikutkan pada pembahasan ini, sehingga dapat diketahui pengaruh pengarang tersebut dalam suatu tulisan/ karya ilmiah yang diteliti yaitu skripsi. Selain itu, untuk pembahasan keusangan literatur, terdapat 425 sitiran berupa Undang-Undang serta Keputusan Pengadilan juga tidak dimuat, karena jenis literatur ini tidak pernah dikatakan usang.

\section{Pola Sitiran}

Berdasarkan hasil penelitian dari 94 skripsi dapat diketahui terdapat total 9.094 sitiran. Literatur yang disitir pada setiap skripsi menunjukkan jumlah yang cukup beragam. Setiap skripsi menyitir lebih dari 20 literatur yang dicantumkan pada daftar pustaka dengan rata-rata sebanyak 97 sitiran, namun jumlah ini menunjukkan nilai yang berbeda setiap tahun. Rata-rata jumlah sitiran pada tahun 2015 adalah 90 sitiran, pada tahun 2016 rata-rata memiliki 106 sitiran dan tahun 2017 jumlah rata-ratanya adalah 91 sitiran. Adapun mengenai jumlah literatur dalam penulisan tugas akhir, skripsi, tesis dan disertasi memang tidak ada ketentuan baik dari buku pedoman penulisan karya tulis ilmiah maupun dari pendapat ahli. Penulis cenderung menggunakan literatur sesuai dengan kebutuhan dalam menunjung karya tulis ilmiahnya.

\section{a. Jenis Literatur}

Berdasarkan Gambar 1, dapat diketahui bahwa terdapat keragaman dari segi jenis literatur yang digunakan dalam menyusun skripsi. Penggunaan jenis literatur beragam dalam penulisan skripsi tersebut merupakan hal yang baik karena mengandung makna bahwa peneliti mampu memanfaatkan beragam jenis literatur yang ada. Jenis literatur yang paling banyak disitir berdasarkan pada sumber data penelitian adalah buku yaitu $6.074(66,8 \%)$ sitiran. Hal ini sesuai dengan pendapat Uçak (2009) bahwa bidang humaniora cenderung menggunakan buku dan monograf sebagai literatur yang digunakan. Buku banyak disitir karena mudah digunakan dan diperoleh (tersedia di perpustakaan maupun toko-toko 
buku), ketersediaan akses, beda halnya dengan literatur yang membutuhkan akses internet, pengguna perlu memiliki keahlian baik dari segi cara maupun menemukan informasi yang sesuai dengan kebutuhan penelitian.

\section{b. Sumber Literatur}

Jumlah literatur tercetak cenderung signifikan digunakan daripada literatur elektronik yaitu $8.236(90,6 \%)$ sitiran. Kecenderungan tersebut sesuai dengan hasil penelitian Hasugian (2016) yang menyatakan bahwa mahasiswa program studi bidang ilmu eksakta lebih dominan dengan jenis sumber daya informasi elektronik dalam hal penggunaan, akses atau bacaan dibandingkan mahasiswa dari program studi bidang ilmu noneksakta. Literatur tercetak banyak disitir pada skripsi karena mudah diperoleh dan digunakan, sementara bahan elektronik memerlukan keahlian untuk mengakses literatur relevan yang mana jumlahnya sangat banyak dan keterbatasan lain seperti keterbatasan akses, ruang penyimpanan dan lain sebagainya.

\section{c. Bahasa Literatur}

Literatur berbahasa Indonesia cenderung banyak digunakan dalam skripsi mahasiswa Prodi Ilmu Perpustakaan yaitu $8.116(88,55 \%)$ sitiran. Banyaknya jumlah literatur berbahasa Indonesia yang disitir skripsi dapat disebabkan oleh beberapa hal yaitu penguasaan kemampuan berbahasa Inggris dan ketersediaan literatur (Sopari \& Christiani, 2016). Penguasaan bahasa dapat berpengaruh pada pemilihan literatur yang akan disitir, mahasiswa cenderung akan memilih literatur berbahasa Indonesia jika kurang memiliki penguasaan terhadap bahasa asing. Selain itu, walaupun perpustakaan telah menyediakan beragam literatur, namun kebanyakan koleksi berbahasa Inggris tersedia dalam bentuk e-resource sehingga membutuhkan keahlian dalam menemukan literatur yang sesuai dengan kebutuhan dan relevan, walaupun juga terdapat kelebihan dalam sumber elektronik ini, yaitu relatif fleksibel dalam hal ruang dan waktu sehingga bisa diakses kapanpun dan dimanapun.

\section{d. Usia Literatur}

Berdasarkan hasil penelitian ini dapat diketahui bahwa sebagian besar skripsi menyitir literatur dengan rentang usia 0-10 tahun yaitu $6.617(73,3 \%)$ sitiran seperti yang dapat dilihat pada Gambar 2. Penggunaan literatur dengan rentang usia tersebut jika dinilai berdasarkan penghitungan paro hidup masih relatif muda sehingga mengindikasikan bahwa literatur masih berkualitas dan memiliki kemutakhiran data yang terjamin. Adapun dalam penelitian ini diketahui bahwa usia literatur tertua yang digunakan adalah 162 tahun, sedangkan terbaru (mutakhir) yaitu 0 tahun atau terbit pada tahun 2017. Penggunaan literatur usang juga dapat digunakan untuk mendukung suatu penelitian. Hal ini sesuai dengan pendapat Sopari \& Christiani (2016) bahwa penggunaan literatur usang yang digunakan sebagai rujukan pendukung penelitian dapat dilakukan dengan alasan bahwa informasi tersebut masih relevan dengan kajian penelitian, literatur memuat informasi khusus, atau cenderung belum terdapat literatur yang sesuai, relevan, baru, lebih baik maupun lengkap sebagai pengganti literatur usang tersebut.

\section{e. Pola Kepengarangan}

Pengarang atas nama orang yang disitir pada skripsi mahasiswa Program Studi Ilmu Perpustakaan FIA UB lulusan tahun 2015-2017 terdapat 1.321 pengarang. Keragaman mengenai kepengarangan yang digunakan dapat mengindikasikan keragaman tema penelitian karena setiap orang dapat memiliki kepakaran masing-masing. Aspek kepengarangan sangat berpengaruh terhadap keputusan dalam menggunakan literatur untuk disitir karena salah satu kriteria penilaian dokumen disitir adalah berdasarkan kepengarangan. Hal ini sesuai dengan pendapat Putri (2016) bahwa dokumen dengan pengarang yang dianggap figur/pakar dalam bidangnya akan dipersepsi tinggi oleh penyitir, sehingga cenderung berpeluang besar pula untuk disitir. Seseorang memilih pengarang yang akan digunakan dilatarbelakangi oleh beberapa faktor, yaitu: otoritas ilmiah, keahlian atau kecakapannya dalam suatu bidang ilmu, mutu tulisan yang tinggi, produktivitas tinggi dalam menulis karya ilmiah, keluasan promosi tulisan ilmiah dari penerbit, pelopor perkembangan teori di bidangnya, kemudahan akses terhadap dokumen dan lain-lain. 
Berdasarkan Gambar 3 diperoleh data terkait pengarang yang memiliki sitiran terbanyak menunjukkan bahwa 10 peringkat teratas berasal dari dalam negeri. Peringkat pertama pengarang yang paling banyak disitir adalah Sugiyono. Peneliti cenderung lebih banyak mengutip teori mengenai metode penelitian daripada lainnya. Metode penelitian ini berkaitan dengan strategi pengumpulan, analisis, dan interpretasi dalam suatu penelitian (Creswell, 2016). Penggunaan metode sebagai alasan menyitir salah satunya juga dibenarkan oleh hasil penelitian Harwood (2009) bahwa faktor yang dikemukakan responden dalam menyitir dokumen cukup beragam, antara lain adalah untuk memperoleh dukungan utamanya membantu penulis untuk membenarkan (i) topik penelitian mereka, (ii) metode yang digunakan; dan / atau (iii) klaim penulis.

\section{f. Tingkat Keusangan}

Tingkat keusangan yang akan dibahas pada penelitian ini adalah diachronous obsolescence, yaitu menggunakan data tahun terbit sitiran untuk mengetahui median tahun sitiran tanpa mempertimbangkan adanya subjek. Adapun berikut merupakan langkah untuk mengetahui tingkat keusangan yaitu menghitung kelas dan interval sesuai data penelitian, menghitung median data kelompok dilanjutkan mengurangi tahun terbit sumber dengan hasil median data kelompok (Hartinah, 2002):

a. Menentukan kelas

$$
\begin{aligned}
& \mathrm{K}=1+3,3 \log \mathrm{n} \\
& \mathrm{K}=1+3,3 \log 8.603 \\
& \mathrm{~K}=1+3,3(3,9) \\
& \mathrm{K}=1+12,98 \\
& \mathrm{~K}=13,98 \text { (dibulatkan menjadi } 14 \text { ) }
\end{aligned}
$$

b. Menentukan interval

$$
\begin{aligned}
& I=\frac{\text { Data tahun terbesar }- \text { data tahun terkecil }}{K} \\
& I=\frac{2017-1855}{14} \\
& I=11,57 \text { (dibulatkan menjadi } 12 \text { ) } \\
& \text { Lmd }=1998,5 \quad \text { fmd }=4737 \\
& \text { lmd }=3437,5 \quad \text { i }
\end{aligned}
$$

c. Menentukan median data kelompok:

$$
\begin{aligned}
M d & =L m d+\frac{[\text { lmd }]}{f m d} i \\
M d & =1998,5+\frac{[3.437,5]}{4.737} 12 \\
M d & =2007,2
\end{aligned}
$$

Keterangan:

Md $=$ Median Literatur

Lmd= Kelas nyata bawah pada saat frekuensi kumulatif mengandung $\frac{n}{2}$

Lmd $=$ Selisih $\frac{n}{2}$ dengan frekuensi kumulatif sebelum mengandung $\frac{n}{2}$

fmd $=$ Frekuensi data pada saat frekuensi kumulatif mengadung $\frac{n}{2}$

$\mathrm{i}=$ Interval kelas

d. Menghitung paro hidup literatur

Paro hidup literatur

$$
\begin{aligned}
& =\text { tahun sitiran terbaru-median } \\
& =2017-2007,2 \\
& =9,8(\text { dibulatkan menjadi } 10)
\end{aligned}
$$

Berdasarkan penghitungan tersebut, didapatkan data bahwa paro hidup literatur yang disitir mahasiswa Program Studi Perpustakaan FIA UB tahun 2015-2017 adalah 10 tahun. Angka tersebut mengindikasikan bahwa: (a) secara keseluruhan, sitiran skripsi mahasiswa Program Studi Ilmu Perpustakaan FIA UB dikatakan mutakhir bila usianya berada di bawah 10 tahun, (b) seluruh literatur skripsi yang berusia di atas 10 tahun dikatakan usang atau tidak mutakhir, (c) salah satu pertimbangan yang dapat dijadikan acuan penyiangan literatur skripsi mahasiswa Program Studi Ilmu Perpustakaan FIA UB adalah berusia lebih dari 10 tahun. Pada penelitian ini, literatur yang terbit sebelum 2007 dapat dinyataan telah usang. Adapun $5.456(63,42 \%)$ literatur yang disitir dapat dikatakan masih relevan untuk digunakan, sementara 3.147 (36,58\%) lainnya dapat dikatakan usang. Sehubungan dengan mayoritas literatur yang digunakan belum mencapai titik usang ini, maka hal ini menunjukkan bahwa mahasiswa Ilmu Perpustakaan FIA UB tahun 2015-2017 telah memberikan kontribusi dalam 
perkembangan ilmu pengetahuan, khususnya bidang ilmu perpustakaan.

Aspek kemutakhiran/keterbaruan cenderung dijadikan kriteria dalam menilai suatu dokumen untuk disitir. Hal ini sesuai dengan pendapat Putri (2016) yang menyatakan bahwa alasan suatu dokumen disitir yaitu karena memuat kebaruan informasi atau cenderung belum diketahui sebelumnya, selain itu juga ditujukan sebagai pembanding antara dokumen dengan corak baru dan kesesuaian topik penelitian. Adapun waktu penerbitan juga berkaitan erat dengan aspek kemutakhiran/ keterbaruan dokumen ini.

Paro hidup literatur dapat menunjukkan angka yang berbeda. Berdasarkan penelitian yang dilakukan Philip Davis seorang konsultan industri penerbitan di Itacha, New York melalui statistik pengunduhan (proxy yang dapat menentukan pola pembacaan artikel) didapatkan fakta bahwa paro hidup literatur pada publikasi ilmiah di bidang ilmu kesehatan berada di bawah kisaran 2 hingga 3 tahun, kemudian untuk bidang humaniora, fisika, dan matematika berada di kisaran 4 hingga 5 tahun (Bohannon, 2013). Suatu literatur dapat memiliki perbedaan nilai keusangan karena dipengaruhi oleh faktor lokasi, contohnya nilai/ angka keusangan literatur dapat berbeda berdasarkan pada negara maju dan negara berkembang (Mustafa, 2010). Konsep paro hidup literatur berkaitan dengan keusangan ini dapat ditujukan untuk mengetahui pertumbuhan ilmu berdasarkan kecepatan pertumbuhan literatur, karena semakin rendah usia paro hidup literatur sebuah bidang ilmu, maka semakin cepat juga perkembangan ilmu tersebut.

Keusangan literatur ini dinyatakan oleh Mustafa (2010) bersifat relatif artinya tidak bergantung pada waktu, karena terdapat literatur yang baru terbit sekitar lima tahun sudah jarang digunakan lagi, tetapi sebaliknya literatur yang sudah terbit puluhan bahkan ratusan tahun namun masih tetap digunakan oleh banyak orang. Ada dokumen yang sudah usang bahkan sebelum diterbitkan. Setiap orang dapat memiliki pandangan berbeda terhadap keusangan suatu dokumen. Berdasarkan hal tersebut, maka bukanlah suatu keharusan bagi peneliti untuk merujuk literatur terbaru maupun literatur yang dianggap sudah usang, selama suatu literatur masih memenuhi aspek relevansi terhadap penelitian, maka tetap dapat digunakan, namun peneliti sebisa mungkin diharapkan lebih mengutamakan penggunaan literatur relevan yang mutakhir karena ilmu pengetahuan dan teknologi telah mengalami kemajuan pesat saat ini.

\section{E. KESIMPULAN \\ Kesimpulan}

Literatur yang dominan digunakan sebagai referensi mahasiswa Program Studi Ilmu Perpustakaan FIA UB dalam menyusun skripsi adalah buku, literatur dengan sumber tercetak, ditulis dalam bahasa Indonesia dengan rentang usia 0-10. Selanjutnya, pengarang yang paling dominan disitir adalah Sugiyono, kemudian 10 peringkat teratas pengarang paling banyak disitir berasal dari dalam negeri, yaitu Indonesia. Adapun paro hidup literatur bidang ilmu perpustakaan adalah 10 tahun. Berdasarkan data penelitian juga dapat diketahui bahwa sebagian besar literatur yang digunakan dapat dikatakan masih relevan untuk digunakan.

\section{Saran}

Berdasarkan pada kesimpulan yang diperoleh maka perpustakaan sebaiknya dapat melakukan pertimbangan mengenai pengembangan dan penyiangan koleksi baik dari segi keterbaruan maupun kebutuhan pengguna. Bagi administrator pendidikan di lingkup fakultas diharapkan dapat memberikan kontrol dan bagi mahasiswa diharapkan untuk memperhatikan aspek sitiran maupun tema penelitian skripsi agar kualitas penulisan lebih baik. Selain itu, mengingat adanya beberapa keterbatasan penelitian, maka penelitian serupa mengenai dalil-dalil bibliometrika dapat dilakukan sebagai kajian lanjutan. 


\section{DAFTAR PUSTAKA}

Alderman, J. (2014). Primary, secondary, and tertiary sources. Diakses 28 April 2019, dari https://digitalcommons.unf.edu/cgi/viewc ontent.cgi? article $=1023 \&$ context $=$ bliss.

Arao, L. H., Veloso, M. J., Santos, C., Vânia, E., Da, L., \& Guedes, S. (2015). The half-life and obsolescence of the literature science area: a contribution to the understanding the chronology of citations in academic activity. Qualitative and Quantitative Methods in Libraries (QQML), 4, 603-610.

Bohannon, J. (2013). The secret half-lives of scientific papers. Diakses 28 April 2019, dari http://www.sciencemag.org/ news/2013/12/secret-half-lives-scientificpapers.

Creswell, J. W. (2016). Research design: pendekatan metode kualitatif, kuantitatif, dan campuran edisi keempat. Yogyakarta: Pustaka Pelajar.

Darmawan, D. (2014). Metode penelitian kuantitatif. Bandung: Remaja Rosdakarya.

Fakultas Ilmu Administrasi Universitas Brawijaya. 2012. Pedoman penyusunan dan ujian skripsi Program Sarjana (S1) Fakultas Ilmu Administrasi Universitas Brawijaya Malang 2012/2013. Malang: Fakultas Ilmu Administrasi Universitas Brawijaya.

Guninda, Zakaria, R., \& Christiani, L. (2015). Analisis sitiran jurnal pada skripsi mahasiswa Jurusan Ekonomika dan Bisnis Universitas Diponegoro. Jurnal Ilmu Perpustakaan, 4(2), 39-45.

Hartinah, S. (2002). Analisis sitiran (citation analysis). Depok: Masyarakat Informetrika Indonesia.

Harwood, N. (2009). An interview-based study of the functions of citations in academic writing across two disciplines. Journal of Pragmatics, 41(3), 497-518. https://doi.org/10.1016/j.pragma.2008.06. 001
Hasugian, J. (2016). Analisis penggunaan sumber daya informasi tercetak dan elektronik di Perpustakaan Universitas Sumatera Utara. Universitas Sumatera Utara. Diambil dari http://repository. usu.ac.id/handle/123456789/64518

Lembaga Ilmu Pengetahuan Indonesia. (2013). Peraturan Kepala Lembaga Ilmu Pengetahuan Indonesia nomor 06/E/2013 tentang kode etika peneliti. Diambil $1 \mathrm{Mei}$ 2019, dari http://pusbindiklat.lipi.go.id/ w p - content/plugins / download monitor/download.php?id=48 Mairaj, M. I., \& Naseer, M. M. (2013). Library services and user satisfaction in developing countries: a case study. Health Information and Libraries Journal, 30(4), 318-326. https://doi.org/10.1111/hir.12038

Michael, L. C., \&, \& C., T. M. (2013). ALA glossary of library and information science, fourth edition. Chicago: ALA.

Mustafa, B. (2010). Obsolescence: mengenal konsep keusangan literatur dalam dunia kepustakawanan. Diakses 1 Mei 2019, dari http://repository.ipb.ac.id/handle/1234567 $89 / 32139$

Mutaqin, D. Z. (2015). Buku panduan penyusunan skripsi edisi 1 cetakan 1. Yogyakarta: Deepublish.

Putri, Y. R., Ana I., A. T. K. (2016). Analisis sitiran pada skripsi bertopik perpustakaan sekolah di Program Studi Ilmu Perpustakaan Fakultas Ilmu Budaya Universitas Diponegoro (FIB UNDIP) tahun 2011-2014. Jurnal Ilmu Perpustakaan, 5(2), 361-370.

Rosenberg, Z. (2015). Citation analysis of M.A. Theses and Ph.D. Dissertations in Sociology and Anthropology: An assessment of library resource usage. Journal of Academic Librarianship, 41(5), 680-688. https://doi.org/10.1016/ j.acalib.2015.05.010

Rubin, R. E. (2016). Foundation of library and information science. United States of America: American Library Association. 
Sangam, S. L. \& S. M. (2013). Obsolescence of literature in the field of Psychology. Scientometrics, 44(1), 33-46. https://doi.org/10.1007/BF02458476

Smith, S. (2017). An introduction to bibliometrics and citation analysis. Diakses 1 Mei 2019 dari https://www.aber.ac.uk/ en/media/departmental/informationservice s/pdf/intro-bibliometrics1711.pdf.

Sopari, M., \& Christiani, L. (2016). Karakteristik dan keusangan literatur : suatu kajian bibliometrik pada Skripsi Fakultas Ilmu Budaya Universitas Diponegoro tahun 2015. Jurnal Ilmu Perpustakaan, 5(4), 231-240.
Sutardji. (2011). Kajian artikel tanaman pangan pada Jurnal Penelitian Pertanian Tanaman Pangan. Jurnal Perpustakaan Pertanian, 20(0341), 1-9.

Wallace, D. P. \& Fleet, C. V. (2012). Knowledge into action: research and evaluation in library and information science. California: ABC-CLIO. 


\section{DAFTAR GAMBAR}

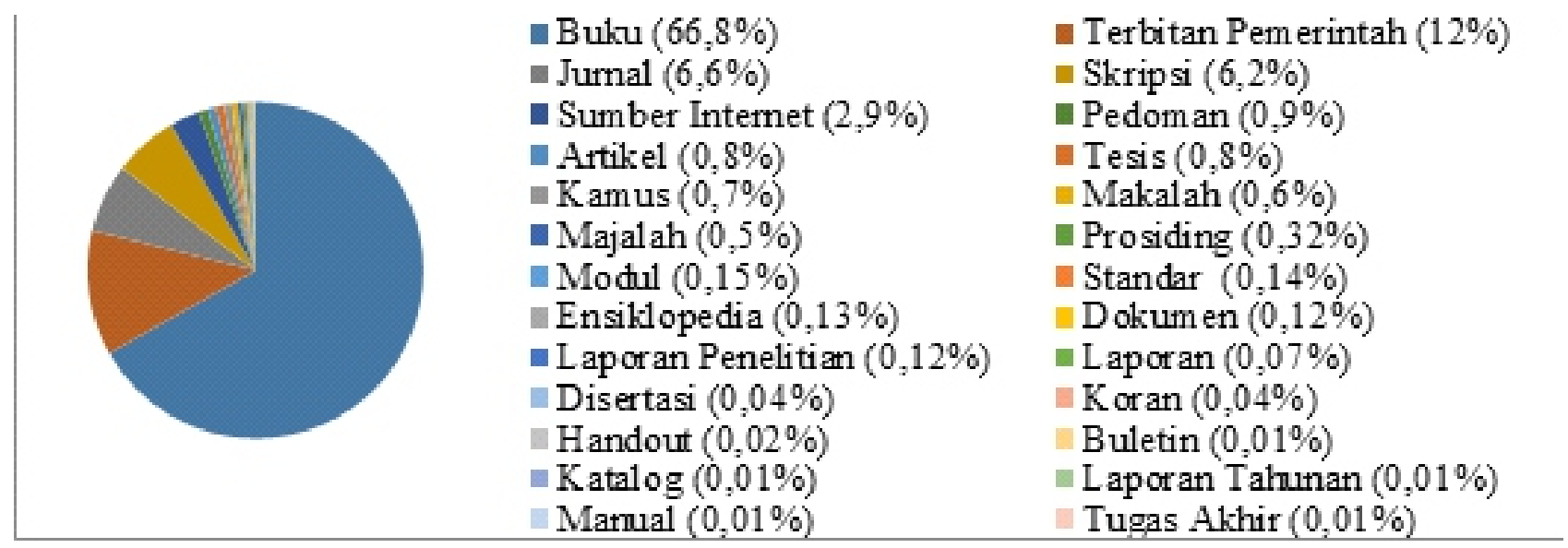

Gambar 1. Persentase Sitiran Berdasarkan Jenis Literatur
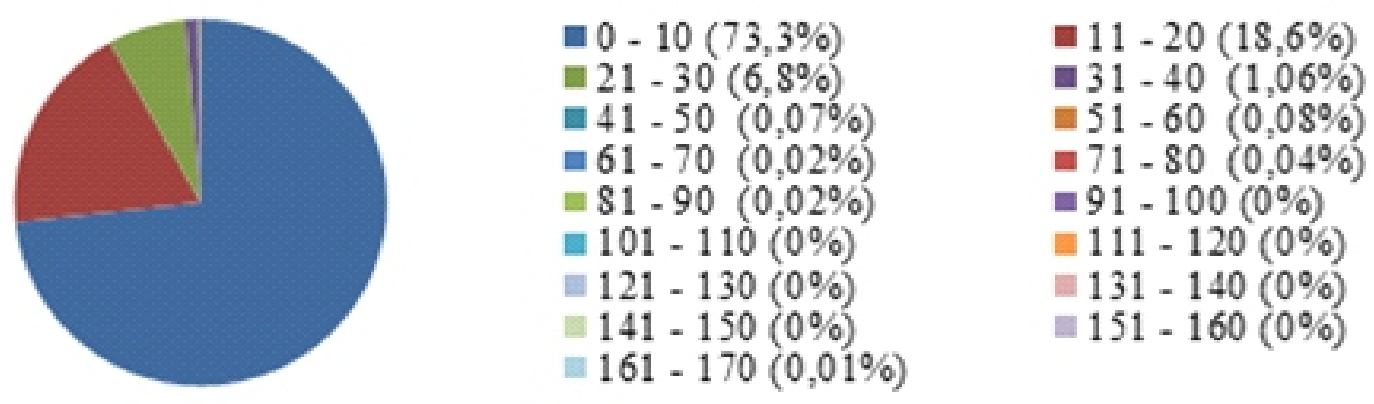

Gambar 2. Persentase Sitiran Berdasarkan Usia Literatur
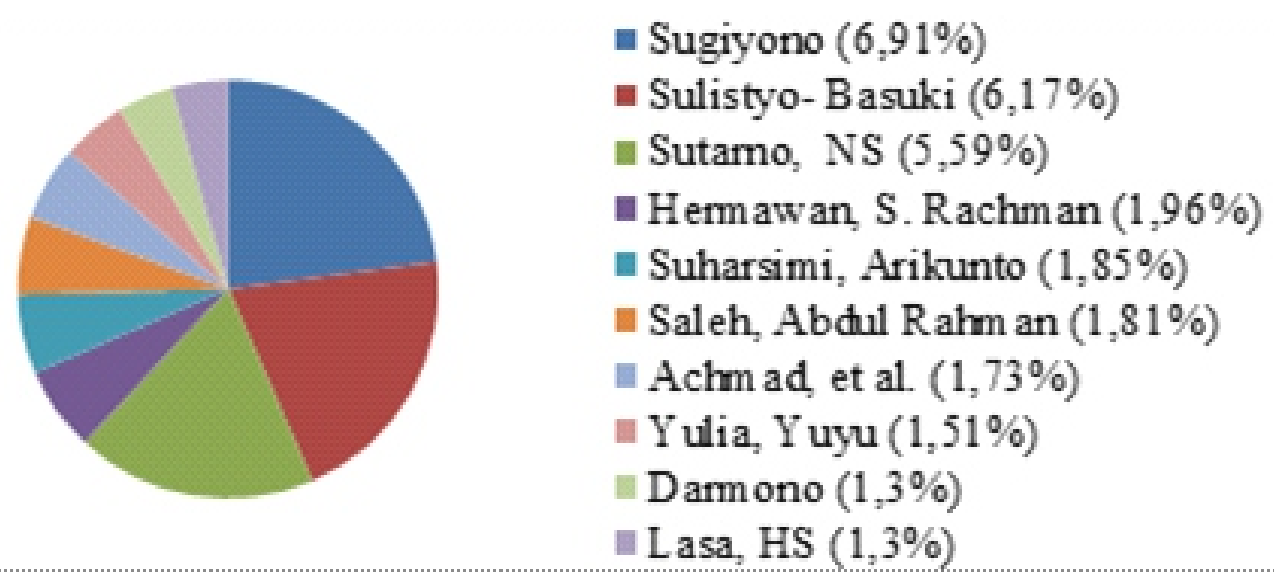

Gambar 3. Persentase Sitiran Berdasarkan Peringkat Pengarang 


\section{DAFTAR TABEL}

Tabel 1. Statistik Koleksi Perpustakaan Universitas Brawijaya Tahun 2017

\begin{tabular}{ll}
\hline \multicolumn{1}{c}{ Jenis Koleksi } & Jumlah Koleksi Perpustakaan Universitas Brawijaya \\
\hline Buku Tercetak & 69.087 judul, 196.219 eksemplar \\
Koleksi Serial & 5.796 eksemplar \\
Koleksi e-resources & 131.050 \\
Grey Literature & 61.793 \\
\hline
\end{tabular}

Sumber: Perpustakaan Universitas Brawijaya, 2017

Tabel 2. Sampel Penelitian

\begin{tabular}{cl}
\hline Tahun & \multicolumn{1}{c}{ Jumlah Sampel } \\
\hline 2015 & $37 \times 94: 123=28,276($ dibulatkan menjadi 28) \\
2016 & $50 \times 94: 123=38,21$ (dibulatkan menjadi 38) \\
2017 & $36 \times 94: 123=27,51$ (dibulatkan menjadi 28) \\
\hline Total & 94 \\
\hline
\end{tabular}

Sumber: Data Primer yang Diolah, 2017

Tabel 3. Panduan pengumpulan input data penelitian

\begin{tabular}{cl}
\hline Jenis Data & \multicolumn{1}{c}{ Informasi yang dimuat } \\
\hline Data Skripsi & $\begin{array}{l}\text { nama penulis, judul, kata kunci, tahun, bahasa, jenis dokumen, jumlah } \\
\text { sitiran } \\
\text { Data Sitiran } \\
\text { daftar pustaka, jenis literatur, tahun terbit, penerbit, kota terbit, } \\
\text { pengarang, sumber, bahasa, jumlah sitiran, usia dokumen }\end{array}$ \\
\hline
\end{tabular}

Sumber: Data Primer yang Diolah, 2017

Tabel 4. Pembagian Periode Tahun Terbit Literatur

\begin{tabular}{ccccc}
\hline No & Tahun & Frekuensi & Frekuensi Kumulatif & Persentase (\%) \\
\hline 1. & $1855-1866$ & 1 & 1 & 0,01 \\
2. & $1867-1878$ & 0 & 1 & 0 \\
3. & $1879-1890$ & 0 & 1 & 0 \\
4. & $1891-1902$ & 0 & 1 & 0 \\
5. & $1903-1914$ & 0 & 1 & 0 \\
6. & $1915-1926$ & 2 & 3 & 0,02 \\
7. & $1927-1938$ & 1 & 4 & 0,01 \\
8. & $1939-1950$ & 0 & 4 & 0 \\
9. & $1951-1962$ & 8 & 12 & 0,09 \\
10. & $1963-1974$ & 5 & 17 & 0,06 \\
11. & $1975-1986$ & 125 & 142 & 1,45 \\
12. & $1987-1998$ & 722 & 864 & 8,39 \\
13. & $1999-2010$ & 4.737 & 5601 & 55,06 \\
14. & $2011-2022$ & 3.002 & 8603 & 34,89 \\
\hline \multicolumn{5}{c}{ Jumlah } \\
\hline
\end{tabular}

Sumber: Data Primer yang Diolah, 2017 